CLINICAL STUDY

\title{
Subclinical hyperthyroidism and the risk of cardiovascular events and all-cause mortality: an updated meta-analysis of cohort studies
}

\author{
Li-bo Yang ${ }^{1,3}$, Dong-qing Jiang ${ }^{2}$, Wen-bo Qi ${ }^{3}$, Tie Zhang ${ }^{3}$, You-lun Feng ${ }^{3}$, Ling Gao ${ }^{4}$ and Jiajun Zhao ${ }^{1}$ \\ ${ }^{1}$ Department of Endocrinology, Provincial Hospital Affiliated to Shandong University, 324 Jing 5 Road, Jinan 250021, People's Republic of China, \\ ${ }^{2}$ Department of Endocrinology, The Second Hospital of Shandong University, Jinan, People's Republic of China, ${ }^{3}$ Department of Endocrinology, Taian City \\ Central Hospital, Taian, People's Republic of China and ${ }^{4}$ Department of Central Laboratory, Provincial Hospital Affiliated to Shandong University, Jinan, \\ People's Republic of China
}

(Correspondence should be addressed to J Zhao; Email: jjzhao@medmail.com.cn)

\begin{abstract}
Objectives: Whether subclinical hyperthyroidism $(\mathrm{SCH})$ results in poor prognosis remains controversial. Our aim was to evaluate the association between SCH and the risk of cardiovascular disease (CVD), cardiovascular mortality, and all-cause mortality by conducting a meta-analysis of cohort studies. Methods: The PubMed and Embase databases were searched through November 2011 to identify studies that met pre-stated inclusion criteria. Relevant information for analysis was extracted. Either a fixed or a random effects model was used to calculate the overall combined risk estimates.

Results: Seventeen cohort studies were included in this meta-analysis. The overall combined relative risks for individuals with SCH compared with the reference group were 1.19 (95\% confidence interval (CI): 1.10 to 1.28 ) for CVD, 1.52 (95\% CI: 1.08 to 2.13) for cardiovascular mortality, and 1.25 (95\% CI: 1.00 to 1.55 ) for all-cause mortality. Subgroup analysis by sample source (community or convenience sample) showed that the significant association for cardiovascular and all-cause mortality only existed when pooling studies from convenience samples. Heterogeneity was observed when pooling studies on the association between SCH and cardiovascular and all-cause mortality. Sensitivity analysis showed omission of each individual study did not significantly change the pooled effects. No evidence of publication bias was observed.

Conclusions: Our findings demonstrated that SCH significantly increased the risk of CVD for the general population and the risk of cardiovascular and all-cause mortality for the individuals with other morbidities.
\end{abstract}

European Journal of Endocrinology 167 75-84

\section{Introduction}

Subclinical hyperthyroidism ( $\mathrm{SCH})$, defined as a serum TSH concentration below the normal range with normal levels of thyroid hormones, affects about $1-2.1 \%$ of the general population $(1,2)$. As a mild form of hyperthyroidism, whether SCH leads to adverse clinical outcomes and should be treated remains controversial. SCH has been found to be associated with a higher risk of atrial fibrillation, hypertension, osteoporosis, and dementia compared with euthyroid subjects in some $(3,4,5,6)$ but not all $(7,8,9)$ studies. Similarly, the findings from the cohort studies on the association between $\mathrm{SCH}$ and cardiovascular disease (CVD), cardiovascular, and all-cause mortality were also inconsistent $(10,11,12,13,14,15,16,17,18,19,20$, $21,22,23,24,25,26,27)$. Lack of randomized clinical trials answering the question whether long-term health outcomes are improved by treatment of SCH made this issue more elusive. A recent guideline suggested treating $\mathrm{SCH}$ in all individuals $\geq 65$ years with other specific comorbidities. However, this recommendation is weak and based on evidence of moderate-to-low quality (28).

Several meta-analyses assessing the relationship between CVD, cardiovascular mortality, and all-cause mortality have been performed previously, providing somewhat conflicting results $(29,30,31)$. Because only a small number of studies were available at that time, these meta-analyses had low power to detect this association precisely. Since the latest meta-analysis had been performed (31), the interest of researchers on this issue rose. A total of 11 new large prospective studies $(17,18,19,20,21,22,23,24,25,26,27)$ on this issue have been published. Now data are sufficient to update the meta-analysis to provide more powerful evidence for physicians and policy-makers. With accumulating data, we aimed to evaluate the 
association between $\mathrm{SCH}$ and the risk of CVD, cardiovascular mortality, and all-cause mortality by conducting a meta-analysis of cohort studies.

\section{Materials and methods}

\section{Search strategy}

Following the proposed Meta-Analysis of Observational Studies in Epidemiology (MOOSE) (32) guidelines to report the present meta-analysis, we conducted a PubMed and Embase database search without restrictions through November 2011 for relevant studies assessing the association between SCH and CVD or mortality (cardiovascular and allcause). The following search terms were used: i) subclinical thyroid disease, $\mathrm{SCH}$, thyroid dysfunction, thyroid hormones, and TSH; ii) CVDs, coronary heart disease (CHD), coronary thrombosis, myocardial ischemia, myocardial infarction, coronary stenosis, coronary restenosis, cerebrovascular disorders, death, mortality, and all-cause mortality; iii) cohort studies, prospective studies, and follow-up studies. In addition, we reviewed the reference lists of retrieved papers and recent reviews.

\section{Study selection}

We first performed an initial screening of titles or abstracts. A second screening was based on full-text review. Studies were considered eligible if they met the following criteria: i) the study design was a cohort study (its definition was as follows: exposure is measured at baseline and the occurrence of outcomes is assessed after a certain time span of follow-up); ii) thyroid function was measured at baseline; iii) the outcome of interest was CVD, cardiovascular, or all-cause mortality; and iv) relative risk (RR) or hazard ratio (HR) and the corresponding 95\% confidence interval (CI) (or data to calculate them) were reported.

\section{Data extraction}

The key exposure variable in this study was the presence or absence of SCH at baseline. Outcomes of interest included major cardiovascular events and cardiovascular and all-cause mortality. Data extraction was performed using a standardized data collection form. The following data were abstracted: first author's name; publication year; country of origin; number, mean age, and sex of the participants; definition of $\mathrm{SCH}$ and cardiovascular events, based on the information provided in the primary studies; prevalence of $\mathrm{SCH}$; study design details, including population source (whether the cohort was recruited from the general population or from participants with a specific comorbidity), starting year of the study, and study duration; whether the reported RR or HR was adjusted for age, gender, or other potential confounders; and losses to follow-up. If a study did not clearly mention any of the above key points, we considered that it had not been performed. Two of us (Yang and Jiang) independently conducted study selection and extracted data. Differences in assessments were resolved by discussion.

\section{Statistical analyses}

The study-specific maximally adjusted RR or HR was used to compute a summary RR and its $95 \%$ CI. HRs were directly considered as RRs. Heterogeneity across studies was tested by the $Q$ and $I^{2}$ statistic (significance level at $P<0.10$ ) (33). The combined risk estimates were computed using either fixed effects models or random effects models with the presence of heterogeneity (34). Because characteristics of populations were not consistent between studies, we further conducted a subgroup analysis to explore the potential effect modification of these variables on outcomes. Meta-regression with restricted maximum likelihood estimation was used to explore possible contributors to heterogeneity. We also investigated the influence of a single study on the overall risk estimate by omitting one study in each turn. Potential publication bias was assessed by Egger's test (linear regression method) (35) and Begg's test (rank correlation method) to evaluate publication bias (36). All analyses were performed using STATA version 11.0 (Stata Corp LP, College Station, TX, USA). A $P$ value $<0.05$ was considered statistically significant, except where otherwise specified.

\section{Results}

\section{Literature search}

Our search strategy produced 2928 reports. Of these, the majority of reports were excluded after the first screening based on the abstracts or titles, mainly because they were reviews, case reports, case-control studies, or not relevant to our analysis. After the fulltext review of 40 papers, 23 studies were excluded for the following reasons: no specific data on the definition of $\mathrm{SCH}$ or no inclusion of $\mathrm{SCH}(37,38,39,40,41,42$, $43,44,45,46,47,48,49,50,51,52)$, no cohort study $(9,53)$, no outcomes of interest $(6,54)$, no detailed data to calculate RRs $(21,55)$, and repeated data with another study (56). Two studies $(10,11)$ meeting the inclusion criteria did not provide detailed data to calculate RRs and CIs. We obtained RRs and CIs from the study by Ochs et al. (30). Finally, 17 studies $(10,11,12,13,14,15,16,17,18,19,20,22$, $23,24,25,26,27)$ were included in our metaanalysis. A flow chart showing the study selection is shown in Fig. 1. 


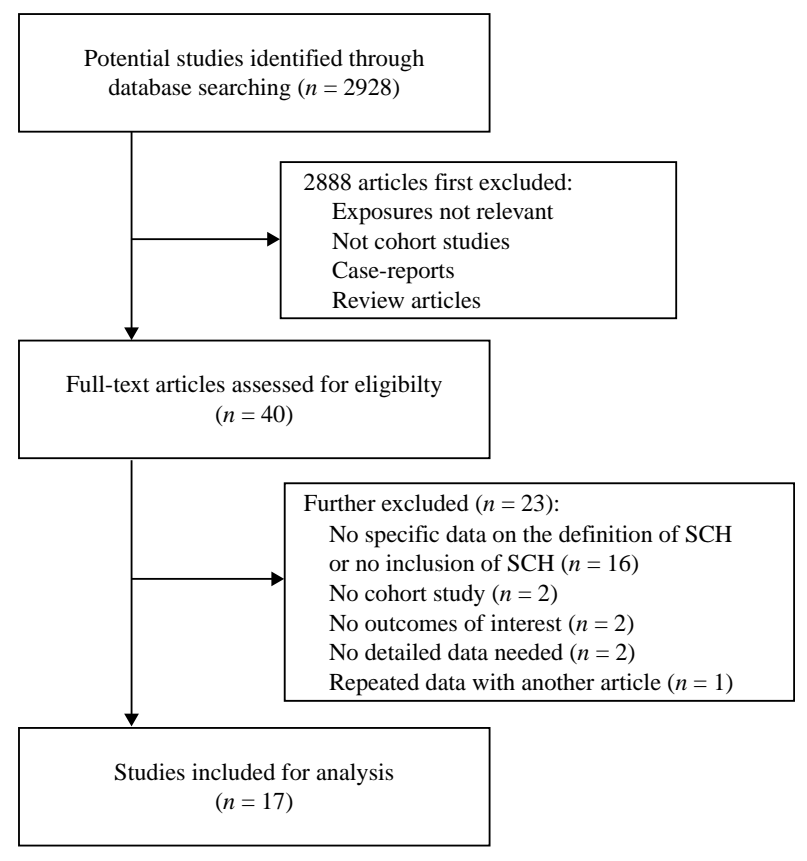

Figure 1 Flow chart of study selection illustrating literature search for cohort studies.

\section{Study characteristics and quality assessment}

The characteristics of 17 cohort studies were summarized in Table 1. These studies were published between 2001 and 2011. Most studies were conducted in Europe. The mean length of the follow-up ranged from 2 to 20 years. In most studies, participants were recruited from communities, whereas in five studies, participants were recruited from convenience samples $(15,16,18,25,27)$. Eight studies used the secondgeneration method for TSH assay $(10,11,15,16,18$, $23,24,26)$ and nine studies used the third-generation method $(12,13,14,17,19,20,22,25,27)$. Most studies had a TSH cut-off value of $0.25-0.5 \mathrm{mU} / \mathrm{l}$ with normal free thyroxine $\left(\mathrm{FT}_{4}\right)$ level. Two studies defined $\mathrm{SCH}$ as low TSH levels without a reported $\mathrm{T}_{4}$ measurement $(14,18)$. The prevalence of SCH ranged from 1.4 to $14.7 \%$. Seven studies $(10,11,15,16,18,23,26)$ repeatedly measured thyroid functions over the follow-up and the others made single baseline measurements. The definition of cardiovascular events varied greatly across all studies. In most studies, it referred to a combined end point including various kinds of heart diseases and one study even included cerebrovascular disease (24). Three studies limited CVD to CHD $(12,13,22)$. CHD was defined as acute myocardial infarction, angina pectoris, and other ischemic heart disease. All outcome assessments were from medical records and hospital databases. Most studies adjusted for a group of conventional risk factors for CVD, including age, BMI, blood pressure, diabetes, cholesterol, smoking, etc. Two studies adjusted for only age and sex (10) or sex and education (11). One study made no adjustments (16). Subjects with thyroid medications were excluded from ten studies (10, 13, $15,17,19,20,22,23,25,26)$ and included in four studies $(11,14,18,24)$, while two studies $(18,24)$ did not specifically refer to this issue. One study (12) included subjects with self-reported thyroid disease but adjustment was made in the calculation of RRs. Losses to follow-up were lower than $5 \%$ in all except one study (11) in which the loss was $13 \%$. The Newcastle-Ottawa Scale (57) was adopted in our quality assessment. As shown in Table 2, the full score was 9 and all studies scored 6 or higher.

\section{SCH and risk of CVD}

Eleven eligible studies on the association between SCH and CVD were pooled. Two studies were from convenience samples $(18,27)$. The RRs for the association varied from 0.91 to 1.98 across studies. Most studies failed to show a significantly positive relationship between SCH and CVD except one study (23). However, as shown in Fig. 2A, the summary RR from the fixed effects model was 1.19 (95\% CI: 1.10 to 1.28$)$ with no evidence of heterogeneity $\left(P=0.48, I^{2}=0.0 \%\right)$. For combining studies from the community sample, the summary RR was 1.30 (95\% CI: 1.16 to 1.47 ; $P=0.00)$. Atrial fibrillation and stroke are other important outcomes of $\mathrm{SCH}$, but a sub-analysis was restricted because only two studies specifically refer to atrial fibrillation (13) and stroke (24) as an end point respectively.

\section{SCH and risk of cardiovascular mortality}

The RRs of 12 eligible studies on the association between SCH and cardiovascular mortality were combined with three studies from convenience samples $(15,16,25)$. The summary RR for cardiovascular mortality was 1.52 (95\% CI: 1.08 to 2.13$)$ with a moderate degree of heterogeneity $(P=0.084$, $I^{2}=38.5 \%$ ) (Fig. 2B). Sub-analysis by sample source showed that the summary RR was 1.26 (95\% CI: 0.94 to 1.68) when restricting to studies from community samples and 3.21 (95\% CI: 1.66 to 6.21) when restricting to those from convenience samples.

\section{SCH and risk of all-cause mortality}

Twelve studies were pooled to calculate the overall RR for all-cause mortality with three studies from convenience samples $(15,16,25)$. A borderline significant association was observed when combining all studies (RR: 1.25 (95\% CI: 1.00 to 1.55$)$; $P=0.05$ ) with the presence of heterogeneity $\left(P=0.03, I^{2}=48.0 \%\right)$ (Fig. 2C). Significant difference between $\mathrm{SCH}$ and the reference group disappeared when combining studies from community samples (RR: 1.13 (95\% CI: 0.91 to 1.41); $P=0.26$ ) but existed when pooling those 
Table 1 Characteristics of 17 cohort studies.

\begin{tabular}{|c|c|c|c|c|c|c|}
\hline Reference & $\begin{array}{l}\text { Location/ } \\
\text { initial year }\end{array}$ & $\begin{array}{l}\text { Duration } \\
\text { (years) }\end{array}$ & $\begin{array}{l}\text { Sample size/ } \\
\text { mean age (years) }\end{array}$ & $\begin{array}{l}\text { TSH cut-off value } \\
(\mathrm{mU} / \mathrm{l}) \text { (percentage } \\
\text { of } \mathrm{SCH})\end{array}$ & Outcomes & Adjustment for covariates \\
\hline (10) & UK/1988 & 8.2 & 1191 adults/70.4 & $<0.5(5.9)$ & $\begin{array}{l}\text { CVD } \\
\text { Cardiovascular } \\
\text { mortality } \\
\text { All-cause mortality }\end{array}$ & Age and sex \\
\hline (16) & Germany/NR & 2 & 93 adults/77 & $<0.1(14.7)$ & $\begin{array}{l}\text { Cardiovascular } \\
\text { mortality } \\
\text { All-cause mortality }\end{array}$ & NR \\
\hline (11) & $\begin{array}{l}\text { The Nether- } \\
\text { lands/1997 }\end{array}$ & 3.7 & 558 adults/85 & $<0.3(3)$ & $\begin{array}{l}\text { CVD } \\
\text { Cardiovascular } \\
\text { mortality } \\
\text { All-cause mortality }\end{array}$ & Sex and education \\
\hline (12) & Australia/1981 & 20 & 1926 adults/49.8 & $<0.4(1.8)$ & $\begin{array}{l}\text { CVD } \\
\text { Cardiovascular } \\
\text { mortality }\end{array}$ & $\begin{array}{l}\text { Age, sex, BMI, smoking, } \\
\text { diabetes, TC, TG, BP, } \\
\text { anti-hypertensive therapy, } \\
\text { exercise, thyroid disease }\end{array}$ \\
\hline (13) & USA/1989 & 12.5 & 3233 adults/72.7 & $<0.44(1.5)$ & $\begin{array}{l}\text { CVD } \\
\text { Cardiovascular } \\
\text { mortality } \\
\text { All-cause mortality }\end{array}$ & $\begin{array}{l}\text { Age, sex, CVD and atrial } \\
\text { fibrillation at baseline, CRP, } \\
\text { smoking, diabetes, LDL-C, } \\
\text { lipid-lowering and thyroid } \\
\text { medications during follow-up, } \\
\text { race, hypertension, BMI }\end{array}$ \\
\hline (14) & USA/1986 & 11.9 & 487 adults/71.7 & $<0.5(4.1)$ & $\begin{array}{l}\text { CVD } \\
\text { Cardiovascular } \\
\text { mortality } \\
\text { All-cause mortality }\end{array}$ & $\begin{array}{l}\text { Age, weight, baseline use of } \\
\text { estrogen }\end{array}$ \\
\hline (15) & Italy/2000 & 2.7 & 3121 adults/61.1 & $<0.3(3.1)$ & $\begin{array}{l}\text { Cardiovascular } \\
\text { mortality } \\
\text { All-cause mortality }\end{array}$ & $\begin{array}{l}\text { Age, sex, CHD, levels of TSH, } \\
\mathrm{FT}_{4}, \mathrm{FT}_{3}\end{array}$ \\
\hline (17) & USA/1989 & 12 & 3044 adults/72.6 & $<0.1(1.4)$ & Heart failure & $\begin{array}{l}\text { Age, sex, race, CVD and atrial } \\
\text { fibrillation at baseline, alcohol } \\
\text { use, smoking, diabetes, } \\
\text { hypertension, BMI, LDL-C, } \\
\text { HDL-C, creatinine }\end{array}$ \\
\hline (18) & UK/1993 & 4.5 & 17684 adults/60.5 & $<0.4(\mathrm{NR})$ & CVD & $\begin{array}{l}\text { Age, sex, history of hyper- } \\
\text { thyroidism and CVD, socio- } \\
\text { economic status, diabetes, } \\
\text { age } \times \text { sex interaction }\end{array}$ \\
\hline (22) & UK/1993 & 10.6 & 11554 adults/58.1 & $<0.4(1.87)$ & $\begin{array}{l}\text { CVD } \\
\text { All-cause mortality }\end{array}$ & $\begin{array}{l}\text { Age, sex, smoking, diabetes, } \\
\text { WHR, systolic BP, LDL-C, } \\
\text { HDL-C }\end{array}$ \\
\hline (19) & Germany/1997 & 8.5 & 3651 adults $/ 49.0$ & $<0.25(6.7)$ & $\begin{array}{l}\text { Cardiovascular } \\
\text { mortality } \\
\text { All-cause mortality }\end{array}$ & $\begin{array}{l}\text { Age, sex, smoking, hyper- } \\
\text { tension, stroke, MI, diabetes, } \\
\text { BMI, TC, fibrinogen }\end{array}$ \\
\hline (20) & Brazil/1999 & 7.5 & 1110 adults/56.9 & $<0.45(6.2)$ & $\begin{array}{l}\text { Cardiovascular } \\
\text { mortality } \\
\text { All-cause mortality }\end{array}$ & $\begin{array}{l}\text { Age, sex, hypertension, dia- } \\
\text { betes, CVD, TC, smoking, } \\
\text { waist circumference }\end{array}$ \\
\hline (23) & UK/1993 & 5.6 & $\mathrm{NR} / 66.5^{\mathrm{a}}$ & $<0.4(\mathrm{NR})$ & CVD & $\begin{array}{l}\text { Age } \times \text { sex interaction, history of } \\
\text { CVD, cerebrovascular disease } \\
\text { and renal failure, socioeco- } \\
\text { nomic status, diabetes }\end{array}$ \\
\hline (24) & Denmark/1998 & 5 & 605 adults/68 & $<0.4(2.8)$ & $\begin{array}{l}\text { CVD } \\
\text { Cardiovascular } \\
\text { mortality } \\
\text { All-cause mortality }\end{array}$ & $\begin{array}{l}\text { Age, sex, hypertension, dia- } \\
\text { betes, current smoking }\end{array}$ \\
\hline (25) & Italy/2000 & 2.5 & 1026 adults/67.7 & $<0.3(2.2)$ & $\begin{array}{l}\text { Cardiovascular } \\
\text { mortality } \\
\text { All-cause mortality }\end{array}$ & $\begin{array}{l}\text { Age, sex, smoking, CHD, history } \\
\text { of percutaneous angioplasty, } \\
\text { coronary artery bypass, left } \\
\text { ventricular ejection fraction, } \\
\text { CRP, creatinine, TG }\end{array}$ \\
\hline (26) & $\begin{array}{l}\text { The Nether- } \\
\text { lands/1995 }\end{array}$ & 10.7 & 1219 adults/75.5 & $<0.3(2.8)$ & $\begin{array}{l}\text { Cardiovascular } \\
\text { mortality } \\
\text { All-cause mortality }\end{array}$ & $\begin{array}{l}\text { Age, sex, alcohol use, smoking, } \\
\text { physical activity, TC, number } \\
\text { of chronic diseases, BMI, } \\
\text { mean BP, heart rate }\end{array}$ \\
\hline
\end{tabular}


Table 1 Continued

\begin{tabular}{lllllll}
\hline Reference & $\begin{array}{l}\text { Location/ } \\
\text { initial year }\end{array}$ & $\begin{array}{l}\text { Duration } \\
\text { (years) }\end{array}$ & $\begin{array}{l}\text { Sample size/ } \\
\text { mean age (years) }\end{array}$ & $\begin{array}{l}\text { TSH cut-off value } \\
(\mathrm{mU} / \mathrm{l})(\text { percentage } \\
\text { of SCH) }\end{array}$ & Outcomes & Adjustment for covariates \\
\hline$(27)$ & UK/1992 & NR & 2306 adults/64.5 & $<0.45(2.4)$ & CVD & $\begin{array}{l}\text { Age, sex, hypertension, stroke, } \\
\text { diabetes, cerebrovascular } \\
\text { disease, greater serum } \\
\text { creatinine }\end{array}$ \\
\hline
\end{tabular}

WHR, waist-hip ratio; TC, total cholesterol; TG, triglyceride; CHD, coronary heart disease; CVD, cardiovascular disease; $\mathrm{BP}$, blood pressure; MI, myocardial infarction; $\mathrm{CRP}$, C-reactive protein; $\mathrm{FT}_{4}$, free thyroxine; $\mathrm{FT}_{3}$, free triiodothyronine; NR, not reported.

a Mean age in $\mathrm{SCH}$.

from convenience samples (RR: 1.84 (95\% CI: 1.05 to 3.25); $P=0.03)$.

\section{Exploration of the sources of heterogeneity}

Given that a certain degree of heterogeneity among studies was observed when combining studies on the relationship of $\mathrm{SCH}$ to cardiovascular and all-cause mortality, exploratory univariate meta-regression was performed with age $(<65$ or $\geq 65$ years old), sample source (community or convenience), publication year, length of follow-up ( $<10$ or $\geq 10$ years), ethnicity (Caucasian or non-Caucasian), and sample size ( $<1000$ or $\geq 1000$ participants) as the potential sources of between-study heterogeneity. Sample source was a key contributor to the heterogeneity $(P=0.045)$ among studies on the association between $\mathrm{SCH}$ and cardiovascular mortality. None of the abovementioned variables were identified as a potentially important source of between-study heterogeneity in combining RRs for total mortality. Stratified analysis by assessment of thyroid function (repeated or not) and mean age barely changed the results among studies from community samples (shown in Table 3).

\section{Sensitivity analysis}

Omission of the study by Flynn et al. (18) had moderate influence on the combined RRs of SCH for risk of CVD, changing the summary RR to 1.29 (95\% CI: 1.15 to 1.44). No evidence of any individual study having excessive influence on the pooled effect in combining risk estimates of $\mathrm{SCH}$ for cardiovascular mortality or all-cause mortality was observed.

\section{Publication bias}

The Begg's funnel plot did not show any substantial asymmetry. Egger's regression test also indicated little evidence of publication bias $(P=0.31-0.84$ for all associations).

\section{Discussion}

There is an ongoing debate on whether SCH results in an increased risk of cardiovascular events and mortality. In the present meta-analysis, we explored the association between SCH and CVD, cardiovascular,

Table 2 Quality assessment of eligible studies.

\begin{tabular}{|c|c|c|c|c|c|c|c|c|c|}
\hline Studies & 1 & 2 & 3 & 4 & $5 A$ & $5 B$ & 6 & 7 & 8 \\
\hline (10) & Yes & Yes & Yes & Yes & Yes & No & Yes & Yes & Yes \\
\hline (16) & No & Yes & Yes & Yes & No & No & Yes & Yes & Yes \\
\hline (11) & Yes & Yes & Yes & Yes & No & No & Yes & Yes & No \\
\hline (12) & Yes & Yes & Yes & Yes & Yes & Yes & Yes & Yes & Yes \\
\hline (13) & Yes & Yes & Yes & Yes & Yes & Yes & Yes & Yes & Yes \\
\hline (14) & Yes & Yes & Yes & Yes & Yes & Yes & Yes & Yes & Yes \\
\hline (17) & Yes & Yes & Yes & Yes & Yes & Yes & Yes & Yes & Yes \\
\hline (18) & No & Yes & Yes & Yes & Yes & Yes & Yes & Yes & Yes \\
\hline (22) & Yes & Yes & Yes & Yes & Yes & Yes & Yes & Yes & Yes \\
\hline (19) & Yes & Yes & Yes & Yes & Yes & Yes & Yes & Yes & Yes \\
\hline (20) & Yes & Yes & Yes & Yes & Yes & Yes & Yes & Yes & Yes \\
\hline (23) & Yes & Yes & Yes & Yes & Yes & Yes & Yes & Yes & No \\
\hline (24) & Yes & Yes & Yes & Yes & Yes & Yes & Yes & Yes & Yes \\
\hline (25) & No & Yes & Yes & Yes & Yes & Yes & Yes & Yes & Yes \\
\hline (27) & No & Yes & Yes & Yes & Yes & Yes & Yes & No & No \\
\hline
\end{tabular}

1, exposed cohort truly representative; 2 , controls drawn from the same community; 3 , ascertainment of exposure; 4 , outcome of interest not present at the beginning; $5 \mathrm{~A}$, cohorts controlled for age; $5 \mathrm{~B}$, cohorts controlled for other factor(s); 6 , quality of outcome assessment; 7 , follow-up long enough for outcomes to occur; 8 , complete accounting for cohorts. 


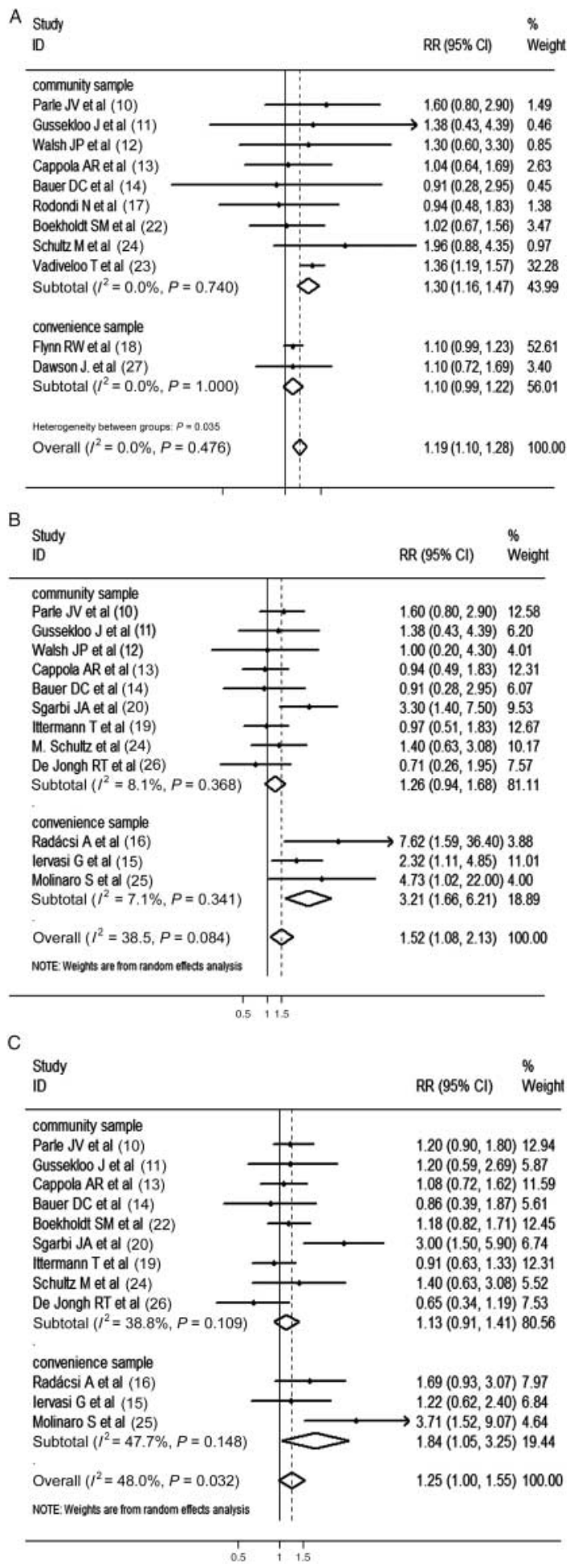

Figure 2 (A) Forest plot showing overall and subgroup analyses on the association between SCH and risk of CVD. (B) Forest plot showing overall and subgroup analysis on the association between $\mathrm{SCH}$ and risk of cardiovascular mortality. (C) Forest plot showing overall and subgroup analysis on the association between $\mathrm{SCH}$ and risk of all-cause mortality. $\mathrm{Cl}$, confidence interval; $\mathrm{RR}$, relative risk. and all-cause mortality by pooling cohort studies. To our knowledge, this is the most comprehensive metaanalysis on this issue to date. Contrary to the results of two previous meta-analyses $(29,30)$, our study provided statistical evidence that $\mathrm{SCH}$ was significantly associated with an increased risk of CVD. Results from the sub-analysis combining community-based studies suggested that the general population with $\mathrm{SCH}$ was at a $31 \%$ increased risk of CVD. Nearly all studies made adjustments for conventional cardiovascular risk factors, including age, BMI, blood pressure, diabetes, cholesterol, and smoking, suggesting that $\mathrm{SCH}$ is probably an independent risk factor for CVD. The mean length of follow-up in primary studies ranged from 2 to 20 years. Such a large interval between the two diseases provides further support. Moreover, a causal relationship between SCH and CVD was plausible from a biological point of view. SCH has been found to be associated with some cardiovascular risk factors, including atrial fibrillation (3), hypertension (4), increased factor X activity (58), and levels of plasma von Willebrand factor (59), fibrinogen, and D-dimer (60). These abnormalities predisposed individuals with SCH to increased CVD risk.

As shown in our subgroup analysis, a significant association between SCH and cardiovascular and allcause mortality was only found among sick individuals. However, given the relatively small number of studies in each subgroup, this result should be interpreted with caution and needs to be confirmed by further studies. A previous meta-analysis (31) pooling seven studies showed that $\mathrm{SCH}$ was significantly associated with all-cause mortality, the result of which appeared to be inconsistent with ours. However, two studies conducted among convenience samples $(15,16)$ were also included in this analysis, and the significant association disappeared after excluding these two studies, which was similar to our result. Though the adverse effects of SCH on the cardiovascular, skeletal, and nervous system have been documented by some studies $(3,4,5,6)$, we speculated that these deleterious effects were not powerful enough to result in a higher rate of mortality in the general population. On the contrary, sick individuals were less tolerant to the harmful effects of SCH.

The cause of SCH includes Graves' disease, toxic multinodular goiter, solitary autonomously functioning nodules, various forms of thyroiditis, central hypothyroidism, and nonthyroidal illness (28). The state of SCH may be transient, especially when the cause is thyroiditis or nonthyroidal illness. It is important to assess thyroid function repeatedly over the course of study to exclude transient SCH. Therefore, a subgroup analysis was performed to evaluate the modification effect of assessment times of thyroid function on the outcome. As shown in Table 3, no significant influence was observed. All included studies did not provide detailed information on the cause of primary $\mathrm{SCH}$, 
Table 3 Stratified analysis of the association of SCH with CVD and mortality. Stratified analysis was performed among studies from community samples. Random effects model was used in combining RRs.

\begin{tabular}{|c|c|c|c|c|}
\hline Stratified factors & Summary RR $(95 \% \mathrm{Cl})$ & $P$ for $Q$ test & $I^{2}(\%)$ & Studies $(n)$ \\
\hline \multicolumn{5}{|l|}{$\mathrm{SCH}$ and risk of CVD } \\
\hline \multicolumn{5}{|l|}{ Mean age (years) } \\
\hline$\geq 65$ & $1.33(1.18$ to 1.51$)$ & 0.71 & 0.0 & 7 \\
\hline$<65$ & $1.07(0.73$ to 1.56$)$ & 0.62 & 0.0 & 2 \\
\hline \multicolumn{5}{|l|}{$\begin{array}{l}\text { Assessment of } \\
\text { thyroid function }\end{array}$} \\
\hline Single at baseline & $1.10(0.85$ to 1.41$)$ & 0.76 & 0.0 & 6 \\
\hline Repeated & 1.37 (1.20 to 1.57$)$ & 0.90 & 0.0 & 3 \\
\hline \multicolumn{5}{|c|}{$\begin{array}{l}\mathrm{SCH} \text { and risk of } \\
\text { cardiovascular mortality }\end{array}$} \\
\hline \multicolumn{5}{|c|}{ Mean age (years) } \\
\hline$\geq 65$ & 1.17 (0.83 to 1.64$)$ & 0.74 & 0.0 & 6 \\
\hline$<65$ & $1.53(0.63$ to 3.71$)$ & 0.07 & 63.2 & 3 \\
\hline \multicolumn{5}{|c|}{$\begin{array}{l}\text { Assessment of thyroid } \\
\text { function }\end{array}$} \\
\hline Single at baseline & $1.26(0.84$ to 1.90$)$ & 0.23 & 27.6 & 6 \\
\hline Repeated & $1.28(0.79$ to 2.10$)$ & 0.41 & 0.0 & 3 \\
\hline \multicolumn{5}{|c|}{$\begin{array}{l}\mathrm{SCH} \text { and risk of all-cause } \\
\text { mortality }\end{array}$} \\
\hline \multicolumn{5}{|c|}{ Mean age (years) } \\
\hline$\geq 65$ & 1.07 (0.87 to 1.33$)$ & 0.60 & 0.0 & 6 \\
\hline$<65$ & 1.37 (0.79 to 2.39$)$ & 0.01 & 77.7 & 3 \\
\hline \multicolumn{5}{|c|}{$\begin{array}{l}\text { Assessment of thyroid } \\
\text { function }\end{array}$} \\
\hline Single at baseline & 1.21 (0.90 to 1.62$)$ & 0.08 & 49.6 & 6 \\
\hline Repeated & $1.02(0.70$ to 1.49$)$ & 0.23 & 31.9 & 3 \\
\hline
\end{tabular}

which hindered us from performing a sub-analysis. Further observational and interventional studies are warranted to explore the effects of various causes of primary $\mathrm{SCH}$ on the clinical outcomes. The availability of only two studies $(16,17)$ that had TSH cut-off values of $<0.1 \mathrm{mU} / \mathrm{l}$ to define SCH made it impossible to perform a suitable sub-analysis. Exclusion of these two studies did not significantly influence the results.

Heterogeneity across studies is often a concern in meta-analysis. It was not surprising that a certain degree of heterogeneity was observed among studies on SCH and mortality given the between-study variation, such as comorbidities, age, length of follow-up, sample source, etc. For this reason, meta-regression was adopted and only the sample source was identified as a potential contributor to heterogeneity in combining RRs for cardiovascular mortality. Because the metaregression was performed on summary data, and not on data from individual study participants, and $<15$ studies were included in our single analysis, this result should be interpreted with caution (61).

Some potential limitations should be considered in the current meta-analysis. First, various definitions of $\mathrm{SCH}$ were used between studies. The absence of uniform diagnostic criteria increased the likelihood of misclassification bias, thereby wrongly estimating the strength of the association. A second limitation was the heterogeneity among studies for the association between $\mathrm{SCH}$ and the risk of mortality. Thirdly, we cannot exclude the possibility of publication bias even though it was not observed by Egger's and Begg's test. Application of modified Egger's linear regression test proposed by Harbord et al. (62) may be the first choice in such a meta-analysis but its use was impeded by the availability of data from the primary papers. Finally, most of the included studies were performed in Europe and America, so it was difficult to say how well the findings can be extrapolated to Asian populations.

Despite these limitations, our analysis possessed several strengths. A major strength of our study was that all the included original studies used a cohort design, which was more powerful to detect a causal relationship than a cross-sectional one. Secondly, most studies adjusted for important confounders, including age, smoking, diabetes, etc. Thirdly, the quality of all included studies was evaluated as good by the Newcastle-Ottawa Scale.

In summary, our data demonstrated that $\mathrm{SCH}$ was associated with an increased risk of CVD for general individuals and with an increased risk of mortality only for sick individuals. Certainly, these results should not be translated into aggressive intervention of $\mathrm{SCH}$. It was reported that treatment with antithyroid drugs for 6 months reduced the average heart rate and ventricular thickness in subjects with SCH (63). The relatively short follow-up and small sample size in this study did not allow evaluation of whether intervention reduced cardiovascular events and mortality. Therefore, well-designed clinical trials are warranted to address these questions. 


\section{Declaration of interest}

The authors declare that there is no conflict of interest that could be perceived as prejudicing the impartiality of the research reported.

\section{Funding}

This research was supported by grants from National Natural Science Foundation of China $(81170794,30971409)$, Natural Science Foundation (ZR2009CZ009), and the international cooperation grant (2011) of Shandong Province of China.

\section{References}

1 Hollowell JG, Staehling NW, Flanders WD, Hannon WH, Gunter EW, Spencer CA \& Braverman LE. Serum TSH, T(4), and thyroid antibodies in the United States population (1988 to 1994): National Health and Nutrition Examination Survey (NHANES III). Journal of Clinical Endocrinology and Metabolism 200287 489-499. (doi:10.1210/jc.87.2.489)

2 Canaris GJ, Manowitz NR, Mayor G \& Ridgway EC. The Colorado thyroid disease prevalence study. Archives of Internal Medicine 2000 160 526-534. (doi:10.1001/archinte.160.4.526)

3 Gammage MD, Parle JV, Holder RL, Roberts LM, Hobbs FD, Wilson S, Sheppard MC \& Franklyn JA. Association between serum free thyroxine concentration and atrial fibrillation. Archives of Internal Medicine $2007 \mathbf{1 6 7}$ 928-934. (doi:10.1001/archinte. 167.9.928)

4 Walsh JP, Bremner AP, Bulsara MK, O'Leary P, Leedman PJ, Feddema P \& Michelangeli V. Subclinical thyroid dysfunction and blood pressure: a community-based study. Clinical Endocrinology 200665 486-491. (doi:10.1111/j.1365-2265.2006.02619.x)

5 Kim DJ, Khang YH, Koh J-M, Shong YK \& Kim GS. Low normal TSH levels are associated with low bone mineral density in healthy postmenopausal women. Clinical Endocrinology 2006 64 86-90. (doi:10.1111/j.1365-2265.2005.02422.x)

6 Bensenor IM, Lotufo PA. Menezes PR \& Scazufca M. Subclinical hyperthyroidism and dementia: the Sao Paulo Ageing \& Health Study (SPAH). BMC Public Health 201010 298. (doi:10.1186/ 1471-2458-10-298)

7 Völzke H, Alte D, Dörr M, Wallaschofski H, John U, Felix SB \& Rettig $\mathrm{R}$. The association between subclinical hyperthyroidism and blood pressure in a population-based study. Journal of Hypertension 200624 1947-1953. (doi:10.1097/01.hjh.00002 $44942.57417 .8 \mathrm{e})$

8 Van der Deure WM, Uitterlinden AG, Hofman A, Rivadeneira F, Pols HA, Peeters RP \& Visser TJ. Effects of serum TSH and FT 4 levels and the TSHR-Asp727Glu polymorphism on bone: the Rotterdam study. Clinical Endocrinology 200868 175-181. (doi:10.1111/ j.1365-2265.2007.03016.x)

9 Bell RJ, Rivera-Woll L, Davison SL, Topliss DJ, Donath S \& Davis SR. Well-being, health-related quality of life and cardiovascular disease risk profile in women with subclinical thyroid disease - a community-based study. Clinical Endocrinology 200766 548-556. (doi:10.1111/j.1365-2265-2007.02771.x)

10 Parle JV, Maisonneuve P, Sheppard MC, Boyle P \& Franklyn JA. Prediction of all-cause and cardiovascular mortality in elderly people from one low serum thyrotropin result: a 10-year cohort study. Lancet 2001358 861-865. (doi:10.1016/S0140-6736 (01)06067-6)

11 Gussekloo J, van Exel E, de Craen AJ, Meinders AE, Frölich M \& Westendorp RG. Thyroid status, disability and cognitive function, and survival in old age. Journal of the American Medical Association 2004292 2591-2599. (doi:10.1001/jama.292.21.2591)

12 Walsh JP, Bremner AP, Bulsara MK, O'Leary P, Leedman PJ, Feddema P \& Michelangeli V. Subclinical thyroid dysfunction as a risk factor for cardiovascular disease. Archives of Internal Medicine 2005165 2467-2472. (doi:10.1001/archinte.165.21.2467)
13 Cappola AR, Fried LP, Arnold AM, Danese MD, Kuller LH, Burke GL, Tracy RP \& Ladenson PW. Thyroid status, cardiovascular risk, and mortality in older adults. Journal of the American Medical Association 2006295 1033-1041. (doi:10.1001/jama. 295.9.1033)

14 Bauer DC, Rodondi N, Stone KL \& Hillier TA \& Study of Osteoporotic Fractures Research Group: Universities of California (San Francisco), Pittsburgh, Minnesota (Minneapolis); Kaiser Permanente Center for Health Research, Portland. Thyroid hormone use, hyperthyroidism and mortality in older women. American Journal of Medicine 2007120 343-349. (doi:10.1016/j. amjmed.2006.04.034)

15 Iervasi G, Molinaro S, Landi P, Taddei MC, Galli E, Mariani F, L'Abbate A \& Pingitore A. Association between increased mortality and mild thyroid dysfunction in cardiac patients. Archives of Internal Medicine 2007167 1526-1532. (doi:10.1001/archinte.167.14. 1526)

16 Radácsi A, Kovács G, Bernard W, Feldkamp J, Horster FA \& Szabolcs I. Mortality rate of chronically ill geriatric patients with subnormal serum thyrotropin concentration: a 2-yr follow-up study. Endocrine 200321 133-136. (doi:10.1385/ENDO:21: 2:133)

17 Rodondi N, Bauer DC, Cappola AR, Cornuz J, Robbins J, Fried LP, Ladenson PW, Vittinghoff E, Gottdiener JS \& Newman AB. Subclinical thyroid dysfunction, cardiac function, and the risk of heart failure. The Cardiovascular Health study. Journal of the American College of Cardiology 200852 1152-1159. (doi:10.1016/j.jacc.2008. 07.009)

18 Flynn RW, Bonellie SR, Jung RT, MacDonald TM, Morris AD \& Leese GP. Serum thyroid-stimulating hormone concentration and morbidity from cardiovascular disease and fractures in patients on long-term thyroxine therapy. Journal of Clinical Endocrinology and Metabolism 201095 186-193. (doi:10.1210/jc.2009-1625)

19 Ittermann T, Haring R, Sauer S, Wallaschofski H, Dörr M, Nauck M \& Völzke H. Decreased serum TSH levels are not associated with mortality in the adult northeast German population. European Journal of Endocrinology 2010162 579-585. (doi:10.1530/EJE-09-0566)

20 Sgarbi JA, Matsumura LK, Kasamatsu TS, Ferreira SR \& Maciel RM. Subclinical thyroid dysfunctions are independent risk factors for mortality in a 7.5-year follow-up: the JapaneseBrazilian thyroid study. European Journal of Endocrinology 2010 162 569-577. (doi:10.1530/EJE-09-0845)

21 Kalra S, Williams A, Whitaker R, Hossain M, Curtis G, Giles M, Sinha A \& Bastawrous SS. Subclinical thyroid dysfunction does not affect one-year mortality in elderly patients after hip fracture: a prospective longitudinal study. Injury 201041 385-387. (doi:10.1016/j.injury.2009.10.013)

22 Boekholdt SM, Titan SM, Wiersinga WM, Chatterjee K, Basart DC, Luben R, Wareham NJ \& Khaw KT. Initial thyroid status and cardiovascular risk factors: the EPIC-Norfolk prospective population study. Clinical Endocrinology $2010 \quad 72$ 404-410. (doi:10.1111/j.1365-2265.2009.03640.x)

23 Vadiveloo T, Donnan PT, Cochrane L \& Leese GP. The Thyroid Epidemiology, Audit, and Research Study (TEARS): morbidity in patients with endogenous subclinical hyperthyroidism. Journal of Clinical Endocrinology and Metabolism 201196 1344-1351. (doi:10.1210/jc.2010-2693)

24 Schultz M, Kistorp C, Raymond I, Dimsits J, Tuxen C, Hildebrandt P \& Faber J. Cardiovascular events in thyroid disease: a population based, prospective study. Hormone and Metabolic Research 201143 653-659. (doi:10.1055/s-0031-1283162)

25 Molinaro S, Iervasi G, Lorenzoni V, Coceani M, Landi P, Srebot V, Mariani F, L'Abbate A \& Pingitore A. Persistence of mortality risk in patients with acute cardiac diseases and mild thyroid dysfunction. American Journal of the Medical Sciences 2011343 65-70. (doi:10.1097/MAJ.0b013e31822846bd)

26 De Jongh RT, Lips P, van Schoor NM, Rijs KJ, Deeg DJ, Comijs HC, Kramer MH, Vandenbroucke JP \& Dekkers OM. Endogenous subclinical thyroid disorders, physical and cognitive function, 
depression, and mortality in older individuals. European Journal of Endocrinology 2011165 545-554. (doi:10.1530/EJE11-0430)

27 Dawson J, Quinn TJ, Walters MR \& Lees KR. Subclinical disorders of thyroid function and risk of cardiovascular events following suspected transient ischemic attack; a cohort study. Stroke 2011 423 (e348). (doi:10.1161/STR.0b013e3182074d9b)

28 Bahn RS, Burch HB, Cooper DS, Garber JR, Greenlee MC, Klein I, Laurberg P, McDougall IR, Montori VM, Rivkees SA, Ross DS, Sosa JA \& Stan MN \& American Thyroid Association, and American Association of Clinical Endocrinologists. Hyperthyroidism and other causes of thyrotoxicosis: management guidelines of the American Thyroid Association and American Association of Clinical Endocrinologists. Endocrine Practice 2011 17 456-520.

29 Singh S, Duggal J, Molnar J, Maldonado F, Barsano CP \& Arora R. Impact of subclinical thyroid disorders on coronary heart disease, cardiovascular and all-cause mortality: a meta-analysis. International Journal of Cardiology 2008125 41-48. (doi:10.1016/ j.ijcard.2007.02.027)

30 Ochs N, Auer R, Bauer DC, Nanchen D, Gussekloo J, Cornuz J \& Rodondi N. Meta-analysis: subclinical thyroid dysfunction and the risk for coronary heart disease and mortality. Annals of Internal Medicine 2008148 832-845.

31 Haentjens P, Van Meerhaeghe A, Poppe K \& Velkeniers B. Subclinical thyroid dysfunction and mortality: an estimate of relative and absolute excess all-cause mortality based on time-to-event data from cohort studies. European Journal of Endocrinology 2008159 329-341. (doi:10.1530/EJE-08-0110)

32 Stroup DF, Berlin JA, Morton SC, Olkin I, Williamson GD, Rennie D, Moher D, Becker BJ, Sipe TA \& Thacker SB. Meta-analysis of observational studies in epidemiology: a proposal for reporting. Meta-analysis Of Observational Studies in Epidemiology (MOOSE) group. Journal of the American Medical Association 2000283 2008-2012. (doi:10.1001/jama.283.15.2008)

33 Higgins JP, Thompson SG, Deeks JJ \& Altman DG. Measuring inconsistency in meta-analyses. BMJ $2003 \quad 327$ 557-560. (doi:10.1136/bmj.327.7414.557)

34 DerSimonian R \& Laird N. Meta-analysis in clinical trials. Controlled Clinical Trials 19867 177-188. (doi:10.1016/01972456(86)90046-2)

35 Egger M, Davey Smith G, Schneider M \& Minder C. Bias in meta-analysis detected by a simple, graphical test. BMJ 1997315 629-634. (doi:10.1136/bmj.315.7109.629)

36 Begg CB \& Mazumdar M. Operating characteristics of a rank correlation test for publication bias. Biometrics $1994 \mathbf{5 0}$ 1088-1101. (doi:10.2307/2533446)

37 Goldman MB, Monson RR \& Maloof F. Cancer mortality in women with thyroid disease. Cancer Research 199050 2283-2289.

38 Bossoni S, Cossi S, Marengoni A, De Martinis M, Calabrese P, Leonardi R, Giustina A, Romanelli G \& Grassi V. The negative role of subclinical thyrotoxicosis on the outcome of hospitalized geriatric patients. Journal of Endocrinological Investigation 2002 25 (10 suppl) 64-65.

39 Davis PJ \& Davis FB. Hyperthyroidism in patients over the age of 60 years. Clinical features in 85 patients. Medicine 197453 161-181. (doi:10.1097/00005792-197405000-00001)

40 Friberg L, Drvota V, Bjelak AH, Eggertsen G \& Ahnve S. Association between increased levels of reverse triiodothyronine and mortality after acute myocardial infarction. American Journal of Medicine $2001 \quad 111$ 699-703. (doi:10.1016/S0002-9343 (01)00980-9)

41 Kaptein EM, Weiner JM, Robinson WJ, Wheeler WS \& Nicoloff JT. Relationship of altered thyroid hormone indices to survival in nonthyroidal illnesses. Clinical Endocrinology 198216 565-574. (doi:10.1111/j.1365-2265.1982.tb03173.x)

42 Nyirenda MJ, Clark DN, Finlayson AR, Read J, Elders A, Bain M, Fox KA \& Toft AD. Thyroid disease and increased cardiovascular risk. Thyroid 200515 718-724. (doi:10.1089/thy.2005.15.718)
43 Peters A, Ehlers M, Blank B, Exler D, Falk C, Kohlmann T, FruehwaldSchultes B, Wellhoener P, Kerner W \& Fehm HL. Excess triiodothyronine as a risk factor of coronary events. Archives of Internal Medicine 2000160 1993-1999. (doi:10.1001/archinte.160.13.1993)

44 Alevizaki M, Synetou M, Xynos K, Pappa T \& Vemmos KN. Low triiodothyronine: a strong predictor of outcome in acute stroke patients. European Journal of Clinical Investigation 200737 651-657. (doi:10.1111/j.1365-2362.2007.01839.x)

45 Enia G, Panuccio V, Cutrupi S, Pizzini P, Tripepi G, Mallamaci F \& Zoccali C. Subclinical hypothyroidism is linked to micro-inflammation and predicts death in continuous ambulatory peritoneal dialysis. Nephrology, Dialysis, Transplantation 200722 538-544. (doi:10.1093/ndt/gfl605)

46 Carrero JJ, Qureshi AR, Axelsson J, Yilmaz MI, Rehnmark S, Witt MR, Bárány P, Heimbürger O, Suliman ME, Alvestrand A, Lindholm B \& Stenvinkel P. Clinical and biochemical implications of low thyroid hormone levels (total and free forms) in euthyroid patients with chronic kidney disease. Journal of Internal Medicine 2007262 690-701. (doi:10.1111/j.1365-2796.2007.01865.x) 47 Westerink J, van der Graaf Y, Faber DR, Spiering W \& Visseren FL. Relation between thyroid-stimulating hormone and the occurrence of cardiovascular events and mortality in patients with manifest vascular diseases. European Journal of Cardiovascular Prevention and Rehabilitation, 2012. In press.

48 Flynn RW, Macdonald TM, Jung RT, Morris AD \& Leese GP. Mortality and vascular outcomes in patients treated for thyroid dysfunction. Journal of Clinical Endocrinology and Metabolism 2006 91 2159-2164. (doi:10.1210/jc.2005-1833)

49 Razvi S, Weaver JU, Vanderpump MP \& Pearce SH. The incidence of ischemic heart disease and mortality in people with subclinical hypothyroidism: reanalysis of the Whickham Survey cohort. Journal of Clinical Endocrinology and Metabolism 201095 1734-1740. (doi:10.1210/jc.2009-1749)

50 Pearce EN, Yang Q, Benjamin EJ, Aragam J \& Vasan RS. Thyroid function and left ventricular structure and function in the Framingham Heart Study. Thyroid 201020 369-373. (doi:10.1089/thy.2009.0272)

51 Park YJ, Lee YJ, Choi SI, Chun EJ, Jang HC \& Chang HJ. Impact of subclinical hypothyroidism on the coronary artery disease in apparently healthy subjects. European Journal of Endocrinology 2011165 115-121. (doi:10.1530/EJE-11-0014)

52 McQuade C, Skugor M, Brennan DM, Hoar B, Stevenson C \& Hoogwerf BJ. Hypothyroidism and moderate subclinical hypothyroidism are associated with increased all-cause mortality independent of coronary heart disease risk factors: a PreCIS database study. Thyroid 201121 837-843. (doi:10.1089/thy. 2010.0298)

53 Ceresini G, Lauretani F, Maggio M, Ceda GP, Morganti S, Usberti E, Chezzi C, Valcavi R, Bandinelli S, Guralnik JM, Cappola AR, Valenti G \& Ferrucci L. Thyroid function abnormalities and cognitive impairment in elderly people: results of the Invecchiare in Chianti study. Journal of the American Geriatrics Society 200957 89-93. (doi:10.1111/j.1532-5415.2008.02080.x)

54 Dörr M, Ittermann T, Aumann N, Obst A, Reffelmann T, Nauck M, Wallaschofski H, Felix SB \& Völzke H. Subclinical hyperthyroidism is not associated with progression of cardiac mass and development of left ventricular hypertrophy in middle-aged and older subjects: results from a 5-year follow-up. Clinical Endocrinology 201073 821-826. (doi:10.1111/j.1365-2265.2010.03882.x)

55 van den Beld AW, Visser TJ, Feelders RA, Grobbee DE \& Lamberts SW. Thyroid hormone concentrations, disease, physical function, and mortality in elderly men. Journal of Clinical Endocrinology and Metabolism 200590 6403-6409. (doi:10.1210/jc.2005-0872)

56 Singer RB. Mortality in a complete 4-year follow up of 85-yearold residents of Leiden, classified by serum level of thyrotropin and thyroxine. Journal of Insurance Medicine 200638 14-19.

57 Wells GA, Shea B, O'Connell D, Peterson J, Welch V, Losos M \& Tugwell P. The Newcastle-Ottawa Scale (NOS) for assessing the quality of nonrandomised studies in meta-analyses. Ottawa, Ontario: Ottawa Health Research Institute, University of Ottawa; available at: http://www.ohri.ca/programs/clinical_epidemiology/oxford.htm. 
58 Patanè S \& Marte F. Intermittent changing axis deviation with intermittent left anterior hemiblock during atrial flutter with subclinical hyperthyroidism. International Journal of Cardiology 2009135 e37-e39. (doi:10.1016/j.ijcard.2008.03.023)

59 Coban E, Aydemir M, Yazicioglu G \& Ozdogan M. Endothelial dysfunction in subjects with subclinical hyperthyroidism. Journal of Endocrinological Investigation 200629 197-200.

60 Coban E \& Aydemir M. Levels of plasma fibrinogen and D-dimer in subjects with subclinical hyperthyroidism. Medical Science Monitor 200814 CR42-CR46.

61 Thompson SG \& Higgins JP. How should meta-regression analyses be undertaken and interpreted? Statistics in Medicine $2002 \mathbf{2 1}$ 1559-1573. (doi:10.1002/sim.1187)
62 Harbord RM, Egger M \& Sterne JA. A modified test for small-study effects in metaanalyses of controlled trials with binary endpoints. Statistics in Medicine 200625 3443-3457. (doi:10.1002/sim.2380) 63 Sgarbi JA, Villaca F, Garbeline B, Villar HE \& Romaldini JH. The effects of early antithyroid therapy for endogenous subclinical hyperthyroidism on clinical and heart abnormalities. Journal of Clinical Endocrinology and Metabolism $2003 \mathbf{8 8} 1672-1677$. (doi:10.1210/jc.2002-021046)

Received 10 January 2012

Revised version received 11 April 2012

Accepted 24 April 2012 